\title{
DISCLOSURE QUALITY AND STOCK RETURNS IN THE UK
}

\author{
Khaled Hussainey ${ }^{1}$ \\ University of Stirling
}

Sulaiman Mouselli

Bangor University

\footnotetext{
${ }^{1} \mathrm{We}$ are grateful for helpful comments received at the 2009 British Accounting Association conference, University of Dundee. We are grateful to Richard Slack, Philip Shrives and two anonymous referees for helpful comments. Correspondence should be addressed to Dr. Khaled Hussainey, Accounting \& Finance Division, Stirling Management School, University of Stirling, Stirling, FK9 4LA, Scotland, UK. Email: Khaled.Hussainey@stir.ac.uk.
} 


\begin{abstract}
Purpose: The purpose of this paper is to update and re-examine the role of corporate narrative reporting in improving investors' ability to better forecast future earnings change. We also construct a risk factor for disclosure quality (DQ) and test whether such a factor is useful in explaining the time-series variation of UK stock returns.

Design/methodology/approach: We use the return-future earnings regression model to update and re-examine the value relevance of disclosure quality for investors. We also construct a DQ factor and add it to Fama-French three-factor model. This is undertaken in order to investigate the usefulness of such a factor in explaining the time-series variation of UK portfolio returns over and above the role of the original Fama and French factors.
\end{abstract}

Findings: Our paper contributes to the market based accounting research in three crucial ways. Firstly, it offers updated evidence on the usefulness of corporate narrative reporting to investors. Secondly, it offers evidence that the DQ factor is a significant risk factor in the UK. Thirdly, and finally, it finds that the Fama- French factors might contain DQ related information.

Practical implications: Our results suggest that narrative reporting contains value relevant information for the stock market. Therefore, regulators should think about asking companies to produce compulsory narrative sections (i.e. operating and financial reviews) in their annual reports.

Originality/value: To the best of our knowledge, our paper is the first to construct and add a DQ factor in the original Fama-French factors.

Keywords: Narrative disclosure; Future oriented information; Value relevance; Fama-French factors; Stock return; United Kingdom.

Classifications: Research paper 


\section{INTRODUCTION}

There is a fundamental link between accounting information in general, and disclosure quality (DQ) in particular, with regard to the cost of equity capital. In principle, disclosure turns private information into public information. Hence, a higher disclosure level is expected to reduce the cost of equity capital. However, there is still a great level of controversy, not only on the channels at which disclosure quality affects stock returns, but also on the scarce empirical evidence to support the association between disclosure quality and stock returns.

Previous research suggests two possible channels at which disclosure quality affects stock returns. The first channel is based on stock liquidity and has no direct link to asset pricing models (see, for example, Diamond and Verrecchia, 1991). However, the second channel assumes that disclosure quality, as a proxy for information risk, affects stock's beta and therefore its expected returns (see for example Barry and Brown (1985), Coles, Loewenstein and Suay (1995)).

Recent studies suggest that information risk is a non-diversifiable risk that cannot be captured by stock's beta only (see O'Hara, 2003; Easley and O'Hara, 2004; and Leuz and Verrecchia, 2005). We take this one step further and suggest additional risk factors to capture information risk related to disclosure quality similar to Francis et al. (2005), and Core et al. (2008), who advocate a risk factor to capture information risk that is related to accruals quality. 
This paper builds on prior research that investigates the importance of disclosure quality for stock market participants. In order to be thorough, we re-examine the value relevance of future oriented earnings statements in the annual report narratives. In particular, we re-examine the degree to which these statements improve investors' ability to better anticipate future earnings. We expand upon, and update prior research in the UK by Hussainey et al. (2003), Schleicher et al. (2007) and Hussainey and Walker (2009). Hussainey et al. (2003) and Schleicher et al. (2007) provide evidence on the value relevance of disclosure quality for the stock market participants, in order to better forecast future earnings one year ahead. Hussainey and Walker (2009) provide evidence that disclosure helps stock market participants to form better expectations about future earnings for a longer period of time, for example, three years ahead. However, Hussainey and Walker (2009) restrict their sample to companies that pay cash dividends. However, we expand and update the above papers by examining the value relevance of disclosure quality for UK companies - other than just those that pay cash dividends - for forecasting future earnings three years ahead.

Our paper adds to the market-based accounting literature in two crucial aspects. Firstly, consistent with theories that demonstrate a role for information risk in asset pricing, this study investigates the relation between disclosure quality and stock returns for a large sample of firms over the period July 1997 to June 2004 . We show that firms with poor disclosure quality have higher costs of capital than do firms with good disclosure quality.

Secondly, Fama and French $(1993,1996)$ show that risk factors constructed on the basis of book-to-market (HML) and market value (SMB) are incrementally important 
in explaining the time-series variation of US portfolio returns. We construct a disclosure quality (DQ) factor and add it to Fama-French three-factor model, in order to investigate the usefulness of such a factor in explaining the time-series variation of UK portfolio returns over and above the role of the original Fama-French factors. We find that DQ factor (as a proxy for information risk) is a useful risk factor.

The paper proceeds as follows. Section 2 discusses the theoretical background. Section 3 discusses our disclosure measure. Section 4 describes our research methods. Section 5 describes the data. Section 6 presents our empirical findings. Section 7 concludes.

\section{THEORETICAL BACKGROUND}

The theoretical research provides two possible channels at which disclosure quality could affect stock returns. First, researchers, i.e. Diamond and Verrecchia (1991) and Espionsa and Trombetta (2007), argue that a greater disclosure should increase stock liquidity and reduce its risk either by reducing transaction costs or increasing the demand on stock, and consequently reducing the expected returns on the stock.

The second channel at which disclosure level could affect stock returns includes Barry and Brown (1985), Coles and Loewenstein (1988), Handa and Linn (1993), Coles et al. (1995) and Clarkson et al. (1996). They argue that better disclosure quality will reduce the potential investors' estimation risk about the parameters of a stock's future return or payoff distribution. That is, investors attribute more systematic risk to an asset with low information compared to an asset with high information. Both channels 
can be aligned under the concept of information asymmetry, however only the latter assumes that impact of disclosure quality on stock returns works through stock's beta.

Recent studies suggest that information risk is a non-diversifiable risk that cannot be captured by stock's beta only (see O'Hara, 2003; Easley and O'Hara, 2004; and Leuz and Verrecchia, 2005). For example, Easley and O’Hara (2004) show that more public information reduces the risk to uninformed traders holding the stock. They argue that investors require a higher return to hold stocks with less public information. They further suggest that disclosure is priced because informed investors can adjust their portfolios to incorporate good news while uninformed investors cannot.

Furthermore, Kang (2004) studies the relation between disclosure and stock returns. He derives disclosure risk premium to measure the differences in stock returns by comparing a case in which information asymmetry exists with the other case where there is no information asymmetry. He finds that firms with bad disclosure history will have higher disclosure premium in their stock returns.

Traditional asset pricing theory (i.e. Fama, 1991) considers information risk as a diversifiable risk and consequently discards any impact of it on stocks' expected returns. However, Easley and O'Hara (2004) argue that information risk is nondiversifiable because uninformed investors cannot modify their portfolio weights in a similar manner to that of informed investors. More recently, Francis et al. (2005) and Core et al. (2008) suggest a risk factor based on accruals quality as a source of information risk. 
In this paper, we suggest a different proxy for information risk built on the basis of disclosure quality that uses the number of future oriented earnings statements in annual report narratives as a measure of disclosure quality. We argue that the DQ factor is a systematic risk factor that captures information risk. Hence, we expect the DQ factor to be a significant risk factor in pricing stock returns. We test this prediction empirically, on the UK stock returns, by adding a disclosure quality factor to the Fama-French three factor model.

\section{Disclosure QuALiTY MEASURE}

The concept of disclosure quality is very difficult to assess. This is because it refers to the degree to which current and potential investors can read and interpret the information easily (Hopkins, 1996). Measuring investors' perception of the firm's disclosure quality is not an easy task. Consequently, researchers tend to use disclosure quantity as a proxy for disclosure quality (for more discussion, see for example Botosan, 1997; Beattie et al., 2002; Beretta and Bozzolan, 2004 and 2008).

Our DQ scores mainly capture the quantity of future oriented statements. We acknowledge the fact that it is not an easy task to explicitly measure the quality of corporate disclosure. In addition, disclosure quantity alone is not a satisfactory proxy for disclosure quality. However, in a recent article, Beretta and Bozzolan (2004) propose a framework for measuring disclosure quality. They argue that "Quality of disclosure depends both on the quantity of information disclosed and on the richness offered by additional information. While the quantity of disclosure has been discussed in previous literature, little attention has been paid, until now, to the richness of the information in quality. In our view, semantic properties of disclosures about future 
prospects, that is, the richness-determines whether or not the information helps outside investors appreciate the expected impact of disclosed risks on the firms' capability to create value" (page 266).

Based on the framework proposed by Beretta and Bozzolan (2004), we use the quantity and richness of future oriented disclosures as a proxy for the quality of future oriented disclosures. We measure disclosure quantity by counting the number statements containing future prospectus. We use good news information as a proxy for the information richness criterion. This is because good news statements are more likely to help investors to better forecast firm's future prospects.

Prior research shows that good news information in the annual reports dominates bad news information. For example, Bujaki et al. (1999) find that good news disclosures account for $97.5 \%$, while $2.5 \%$ of future oriented information is bad news. This result is consistent with the findings in Clarkson et al. (1992 and 1994) and Clatworthy and Jones (2003). Clarkson et al. (1992 and 1994) find that managers tend to publish favourable future oriented information in their annual reports. The findings in Clatworthy and Jones (2003) suggest that UK companies prefer to report positive aspects of their performance. Finally, we randomly select a sample of future oriented sentences, and carefully read these sentences. We find that $95 \%$ of these sentences reveal good news about the future. This indicates that future oriented information in the annual reports is more likely to contain good news information. Therefore, we use the quantity of future oriented disclosure as a proxy for the quality of future oriented disclosure. 
We adopt the same measure of disclosure quality developed in Hussainey et al. (2003). They generate their disclosure scores for a large sample of UK annual reports automatically by using QSR N6 software. Their measure of disclosure quality is the number of future oriented statements in corporate annual report narrative sections that contain earnings-related topics. We use the same measure of disclosure and we also focus on earnings indicators because Hussainey et al. (2003); Schleicher et al. (2007) and Hussainey and Walker (2009) find that these indicators increase the stock market's ability to foresee future earnings change.

Like Hussainey et al. (2003), we estimate the DQ score for our sample in three steps. In the first step, we search the narrative sections of annual reports for future oriented information. We use the list of future oriented information keywords created by Hussainey et al. (2003, p. 277). This list includes thirty-five keywords as follows: accelerate, anticipate, await, coming (financial) year(s), coming months, confidence (or confident), convince, (current) financial year, envisage, estimate, eventual, expect, forecast, forthcoming, hope, intend (or intention), likely (or unlikely), look forward (or look ahead), next, novel, optimistic, outlook, planned (or planning), predict, prospect, remain, renew, scope for (or scope to), shall, shortly, should, soon, will, well placed (or well positioned), year(s) ahead. Similar to Hussainey et al. (2003) we also take account of future year numbers in the list of future oriented keywords. In the second step, we identify the relevant information to the stock market in assessing the firm's future earnings. For the purpose of the current paper, we use the same list created by Hussainey et al. (2003, p. 280) that is related to earnings indicators. The list contains the following twelve keywords benefit, breakeven, budget, contribution, earnings, eps, loss, margin, profit, profitability, return and trading. Finally, we use 
QSR N6 to count the number of sentences that include a minimum of one future oriented keyword and one earnings indicator, and consider this number our measure of DQ score.

\section{RESEARCH METHODS}

\subsection{THE VALUE RELEVANCE OF DisClosuRE QUALITY}

The article by Collins et al. (1994) is a response to Lev (1989), who notes that the association between returns and current earnings is relatively weak. They investigate two potential factors contributing to the low contemporaneous return-earnings association. One of these factors is earnings' lack of timeliness in capturing valuerelevant events. To capture the intuition that prices lead earnings, they expand the simple return-earnings regression to include future earnings growth variables. Collins et al. (1994: 295) motivate their regression model by assuming the following returngenerating process:

$$
R_{t}=\beta_{0}+\beta_{1} U X_{t}+\sum_{k=1}^{N} \beta_{k+1} \Delta E_{t}\left(X_{t+k}\right)+e_{t}
$$

Where:

$R_{t}$ is the stock return for period $t$,

$X_{t}$ is the growth rate of earnings in period $\mathrm{t}$, $U X_{t}=X_{t}-E_{t-1}\left(X_{t}\right)$ is the unanticipated earnings growth rate

$\Delta E_{t}$ is the revision in market expectations between the beginning and the end of period $t$.

$\mathrm{k}$ is limited to three years ahead.

Collins et al. (1994) suggested that returns in period $t$ are generated by three components: (1) the unanticipated component of the current period's earnings change, $U X_{t},(2)$ the market's revision in expectations about future earnings growth 
rates, $\Delta E_{t}\left(X_{t+k}\right)$ and (3) an orthogonal error term that captures all other influences, $e_{t}$.

To implement equation (1) empirically, one needs to replace unobservable expectations with observable proxy variables. Prior to Collins et al. (1994), researchers such as Warfield and Wild (1992) used realized earnings growth as an observable proxy for the market's expectations to explain stock returns. Equation (2) shows the Warfield and Wild's regression model.

$$
R_{t}=b_{0}+b_{1} X_{t}+\sum_{k=1}^{N} b_{k+1} X_{t+k}+e_{t}
$$

Collins et al. (1994) pointed out that the use of realised earnings growth rates introduces errors-in-variables problems that bias the slope coefficients and $\mathrm{R}^{2}$ downward. The errors-in-variables problems become apparent when one rewrites Equation (2) in terms of variables of interest and measurement errors (Collins et al., 1994: 296):

$$
R_{t}=b_{0}+b_{1}\left[U X_{t}+E_{t-1}\left(X_{t}\right)\right]+\sum_{k=1}^{N} b_{k+1}\left[\Delta E_{t}\left(X_{t+k}\right)+U X_{t+k}+E_{t-1}\left(X_{t+k}\right)\right]+e_{t}
$$

Where:

$U X_{t}$ is the unanticipated component of current earnings growth,

$E_{t-1}\left(X_{t}\right)$ is the portion of current period's earnings growth that is anticipated in period $t-1$,

$E_{t-1}\left(X_{t+k}\right)$ is the portion of period $t+k$ 's earnings growth that is anticipated in period $t-1$,

$U X_{t+k}$ is the component of period $t+k$ 's earnings growth generated by surprises in periods $t+1$ to $t+k$.

Comparing equation (2) with equation (3), it can be seen that equation (2) raises a number of measurement error problems. Firstly, $X_{t}$ differs from $U X_{t}$ by the 
expectations from $E_{t-1}\left(X_{t}\right)$. Secondly, $X_{t+k}$ differs from $U X_{t+k}$ in a number of aspects. The market may already know information about $X_{t+k}$ at time point $t-1$. In other words, the parameter associated with $E_{t-1}\left(X_{t+k}\right)$ may be non-zero. Additionally, new information about $X_{t+k}$ may be available to the market between time point $t$ and time point $t+1$. This is indicated by the term $U X_{t+k}$.

An important observation in Collins et al. (1994) is that one can mitigate these measurement error problems by the inclusion of errors-in-variables proxies in the augmented regression model. Crucially, Collins et al. (1994) established that the inclusion of such proxies will affect the goodness of fit of the model, only if the reason for the poor performance of the simple return-earnings regression is "prices leading earnings'. If value-irrelevant noise is the cause of the poor statistical performance of the standard return-earnings model, then the goodness of fit of Equation (2) will not be improved by adding these proxies.

Collins et al. (1994) suggested three measurement error proxies. These are lagged earnings yield, $E P_{t-1}$, current growth in book value of assets, $A G_{t}$ and future periods' returns, $R_{t+k}$. Including these proxies in equation (2) yields the following expanded regression model $^{2}$ :

$$
R_{t}=b_{0}+b_{1} X_{t}+\sum_{k=1}^{N} b_{k+1} X_{t+k}+\sum_{k=1}^{N} b_{k+N+1} R_{t+k}+b_{2 N+2} E P_{t-1}+b_{2 N+3} A G_{t}
$$

The first measurement error proxy for expected future earnings growth is the lagged earnings yield variable, $E P_{t-1}$. This variable is defined as period $t-1$ 's earnings over price at the start of the return window for period $t$. Given that price impounds

\footnotetext{
${ }^{2}$ Equation (4) is re-produced form Collins et al.’s (1994:297) Equation (6).
} 
information about future earnings, $E P_{t-1}$ proxies for the market's forecast of further earnings growth [i.e., proxies for $E_{t-1}\left(X_{t}\right)$ and $\left.E_{t-1}\left(X_{t+k}\right)\right]$. It is well known that prices incorporate information about future earnings. Therefore, a high price in relation to last year's earnings signals high expected earnings growth for the current and future years. As the earnings yield variable and expected earnings growth (the measurement error) are negatively associated, the coefficient on $E P_{t-1}$ should be positive. This is true because this proxy serves to subtract the noise element from realised earnings growth.

The second proxy is the asset growth variable, $A G_{t}$. Higher asset growth indicates that managers increase their production capacity due to an expectation of a higher demand for their product in the future. Such an expansion should lead to higher expected earnings growth. Given that asset growth and expected future earnings changes are positively associated, the coefficient on $A G_{t}$ is forecasted to be negative.

Thirdly, and finally, the measurement error proxy for $U X_{t+k}$ is future periods' returns, $R_{t+k}$. Unanticipated future events that lead to higher (lower) earnings growth in period $t+k$ should also lead to positive (negative) returns in the period when the news becomes available to the market. Hence, a positive relation between $U X_{t+k}$ and future returns is expected to result in negative coefficients on the return variables in Equation (4). ${ }^{3}$

\footnotetext{
3 The use of the future period returns proxy is widely used in prior research (see, for example, Lundholm and Myers, 2002, Oswald and Zarowin, 2007; Hussainey and Walker, 2009; Orpurt and Zang, 2009). However, it should be noted that observed future period returns are not good proxy for unexpected future earnings because they contain both anticipated and unanticipated events. This leads to a cross-sectional correlation across firms within a year and a time series correlation within the same firm (Hanlon et al., 2007:16). This introduces endogeneity problem into the regression analyses. Consequently, the current paper used the new method recommended by Petersen (2008) to solve this problem. Following Petersen (2008) we included year dummies to control for the time series
} 
We employ the multiple regression model introduced by Collins et al. (1994) and further developed by Hussainey and Walker (2009) to study the effect of corporate disclosure quality on the association between current annual stock returns and current and future annual earnings as follows:

$$
\begin{aligned}
& R_{t}=b_{0}+b_{1} X_{t}+b_{2} X_{t 3}+b_{3} R_{t 3}+b_{4} A G_{t}+b_{5} E P_{t-1} \\
& b_{6} D+b_{7} D^{*} X_{t}+b_{8} D^{*} X_{t 3}+b_{9} D^{*} R_{t 3}+b_{10} D^{*} A G_{t}+b_{11} D^{*} E P_{t-1}+e_{t}
\end{aligned}
$$

where:

$R_{t}$ is the stock return for year $t$.

$X_{t}$ is defined as earnings change deflated by lagged earnings at $t-1$.

$X_{t 3}$ is future earnings over three years.

$R_{t 3}$ is future returns over three years.

$A G_{t}$ is the growth rate of total book value of assets for period $t$.

$E P_{t-1}$ is earnings of period $t-1$ over price starting four months after the financial year-end of period $t-1$.

$D$ is a dummy variable sets equal to 1 for companies in the top $50 \%$ of the distributions of disclosure scores and 0 otherwise.

As explained in Lev (1989), prior research finds a positive association between current returns and current earnings, so $b_{1}$ is expected to be positive. Collins et al. (1994) also expect that $b_{2}$ should be positive. Positive coefficient on $b_{2}$ indicates that the more that current stock returns incorporates information about future earnings, the higher the expected coefficient on $X_{t 3}$. The prediction on the coefficients of $b_{3}, b_{4}$ and $b_{5}$ have been discussed earlier. Finally, our coefficient of interest is $b_{8}$. The coefficient on $D^{*} X_{t 3}$ measures the extent to which share price expectation of earnings is greater for firms with high future oriented disclosure levels than those with low future oriented disclosure levels. Our main prediction is that $b_{8}$ should be positive if future oriented earnings statements in the corporate annual report narratives

correlation. We also allowed for error clustering within firms (Rogers standard errors) to control for the cross-sectional correlation. 
improve the stock market's ability to predict future earnings changes. We have no particular predictions for $b_{6}, b_{7}, b_{9}, b_{10}$ and $b_{11}$

\subsection{DISCLOSURE QUALITY AND STOCK RETURNS}

Is DQ correctly priced or is it systematically under- or over-valued? This section considers this research question by studying the relationship between DQ and stock returns.

We report answers to a number of questions. The first question we ask is - are stock returns associated with DQ? We respond to the question by investigating whether average returns to portfolios, formed on the basis of sorting firms by DQ, show any pattern as the score in the portfolios move from low to high values of the DQ.

The second question we ask is whether the DQ portfolios exhibit any evidence of significant mis-pricing. Further, we look at whether estimates of mis-pricing increase as the portfolios move from low to high values of DQ. To respond to these questions, we run time-series regressions of monthly portfolio returns on the Fama-French three factor model applied in the UK. We choose the Fama-French model to capture the risk adjustment because Michou et al. (2007) show that Fama-French three factor model outperforms the CAPM in explaining UK stock returns. The constant term in these regressions is interpreted as a statistic capturing under or over-pricing. Specifically, we run the following time series regressions:

$$
R_{i t}-R_{f t}=a_{i}+\beta_{i M}\left(R_{M t}-R_{f t}\right)+\beta_{i H M L} H M L_{t}+\beta_{i S M B} S M B_{t}+\varepsilon_{i t}, i=0 t o 5
$$

where: 
$R_{i t}$ is the return for month t for portfolio i;

$R_{M t}$ is the return on the market for month $\mathrm{t}$;

$R_{f t}$ is the risk-free return for month $\mathrm{t}$;

$S M B_{t}$ is the size factor return for month $\mathrm{t}$; and

$H M L_{t}$ is the book-to-market factor for month t.

The portfolios are a zero DQ portfolio $(i=0)$ and five quintile DQ portfolios ( $i=1$ to 5 ), with firms sorted annually by DQ score and then allocated to the quintile portfolios. The $\alpha_{i}$ is then used to indicate overpricing if it is less than zero or underpricing if it is more than zero.

The third question we ask is whether a factor reflecting the difference in returns between low DQ firms and high DQ firms is useful in addition to the Fama-French three factor model in the UK in explaining the returns of both the previous 6 DQ portfolios and the 20 industry portfolios. Specifically, we run the following regressions:

$R_{i t}-R_{f t}=a_{i}+\beta_{i M}\left(R_{M t}-R_{f t}\right)+\beta_{i H M L} H M L_{t}+\beta_{i S M B} S M B_{t}+\beta_{i D Q} D Q_{t}+\varepsilon_{i t}(7)$

where:

$D Q_{t}$ is the return for month $\mathrm{t}$ for the DQ factor. We use standard t-tests to evaluate the individual significance of the coefficients on the DQ factor and Gibbons et al. (1989) GRS F-test to examine the joint-significance of the intercepts and the seemingly unrelated regressions (SUR) for the joint significance of the coefficients.

We now report on whether DQ is associated with expected returns. The first test involves sorting firms into portfolios to be held for 12 months from July 1 of year t, based upon the DQ score in year t-1. All firms with zero DQ scores are placed into one portfolio (portfolio zero). The remaining firms are sorted into five equally-sized 
portfolios. Value-weighted portfolio monthly returns are then calculated. This process is performed for each of the seven years of data. Average monthly returns, and other features of the various portfolios, are reported in Table 4.

\section{DATA}

Electronic versions of UK annual reports for the years 1996 to 2002 are collected from the Dialog database. We have limited our analysis to that sample period because Dialog covers large cross-sectional annual reports only for this period of time. We do not believe that this might have any effect on the main findings. In addition, we have checked the validity of our data to ensure that our data is valid for analysis. Other validity checks include comparing annual reports collected from Dialog with the original copy of the annual report downloaded from a sample of companies' WebPages. In addition, we compare the data collected from Datastream for the same sample of firms with those reported either in The Financial Times or company financial statements, and we find a significant similarity. This gives an indication of the reliability of the data collected.

The total number of annual reports on Dialog for non-financial firms for this period of time is 8,098 firm-years. Only 7,977 firm-years have Datastream Codes. We have removed firms that change their financial year ends (1312 firm-years). We have also removed firms with missing accounting and return data. This leaves a sample of 3732 firm-year usable observations. Finally, we have deleted outliers defined as observations falling into the top or bottom $1 \%$ of the distribution of any of the regression variables. Schleicher et al (2007) provide evidence that the deletion of outliers has no effect on the validity of the conclusions when examining the effect of 
voluntary disclosure on the returns-earnings association. This reduces the sample to 3528 firm-years usable observations. Accounting and return data for equation 1 are collected from Datastream (see Table 3 for variables definition). To measure the value relevant of disclosure quality, we include a dummy variable, $D$, sets equal to 1 for companies in the top $50 \%$ of the distribution of disclosure scores and 0 otherwise.

Our sample for the construction of Fama-French factors (HML and SMB) uses monthly return data covering all UK listed firms, live and dead, over the period July 1997 to June 2004. We include in our sample companies that have been de-listed from the exchange due to merger or bankruptcy etc. We exclude companies with more than one class of ordinary share, companies with negative book-to-market ratios, and companies that belong to the financial sector. Annual accounting data is obtained from Datastream, and monthly return data from the London Share Price Database (LSPD).

When portfolios are constructed, if a component stock delists during a portfolio holding period, the proceeds from a delisted stock are assumed distributed among other stocks in the portfolio on the basis of their weights. We set delisting returns to 100 percent whenever the LSPD death type is liquidation (7), quotation cancelled for reason unknown (14), receiver appointed/liquidation (16), in administration (20), or cancelled and assumed valueless (21). We proxy for the return on the market portfolio by the value-weighted return on The Financial Times All Share index.

We follow Dimson et al. (2003) in constructing the Fama-French factors. Their process of describing the factors is as follows. At the end of June for each year $t$, 
stocks are allocated to two groups small (S) or big (B), on the basis of being above or below the $70^{\text {th }}$ percentile of the distribution of market value. Stocks are also allocated in an independent sort to three book to market groups, low (L), medium (M) or high (H), according to the breakpoints of the bottom $40 \%$, middle $20 \%$ and top $40 \%$ of the values of BM recorded at the end of year $t-1$. Therefore, six size-BM portfolios (SL, $\mathrm{SM}, \mathrm{SH}, \mathrm{BL}, \mathrm{BM}, \mathrm{BH})$ are constructed as the intersections of the two size and three BM groups. Then, we calculate the value-weighted monthly returns for the six intersected portfolios for the subsequent twelve months.

SMB is defined as the monthly difference between the average of the returns on the three small size portfolios (SL, SM, SH) and the average of the returns on the three big size portfolios $(\mathrm{BL}, \mathrm{BM}, \mathrm{BH})$. HML is calculated as the difference between the average of the returns on the two high $\mathrm{BM}$ portfolios $(\mathrm{BH}, \mathrm{SH})$ and the average of the returns on the two low BM portfolios (BL, SL).

However, the sample for the DQ factor is restricted to all UK non-financial firms on the Dialog database that have at least one annual report in the period 1996-2002. To construct the DQ factor, we partition firms into five groups on the basis of their DQ score. The DQ factor is defined as the difference between the average of the valueweighted two lowest DQ score portfolio returns, and the average of the valueweighted returns on the two highest DQ score portfolios.

Table 1 provides some initial statistics of the various factors. Fama-French factors (SMB and HML) and DQ factor have positive averages, while the excess market return has a negative average, though they are all insignificant. The positive DQ factor, 
although insignificant, suggests that firms with the lowest DQ scores generate higher returns than firms with the highest DQ scores. Additionally, the correlations between the factors, although mainly significant, are relatively low.

In order to perform our asset pricing test, we sort stocks into portfolios according to their DQ score to construct DQ portfolios. However, Lo and Mackinlay (1990) warn against using portfolios formed on the basis of some characteristic that are known to be associated with returns in testing asset pricing models. Furthermore, Berk (2000) shows sorting stocks into portfolios, based on a variable known a priori to be correlated with returns, increases the variation in realized excess returns across portfolios and, hence, biases the test in favour of rejecting an economically correct asset pricing model. Therefore, we use industry portfolios as well in our asset pricing tests.

We have used the London Share Price Database Industrial classification (G17) and the FTSE Industrial Classification Benchmark (ICB) in constructing 20 industry portfolios. Then, we calculated the value-weighted returns of these portfolios on the assumption that they are bought and held for a year. Repeating this process, year by year, results in a time series of portfolio monthly returns from July 1996 to June 2002. The excess returns on these 20 portfolios are the dependent variables in the timeseries regressions. Table 2 provides descriptive statistics for the 20 industry portfolios used in the time-series tests.

\section{RESULTS}

\subsection{THE VALUE RELEVANCE OF DISCLOSURE QUALITY}


Table 3 shows the empirical results of estimating equation (5). As expected, the coefficient associated with $X_{t}$ is positive and significant. The coefficient for $X_{t}$ is 1.53 with a p-value of 0.001 . In addition, the coefficient for $X_{t 3}$ is 0.48 with a p-value of 0.001 . This suggests that current stock price is positively associated with current earnings changes and there is evidence that the stock market is able to anticipate future earnings three years ahead in year $t$. The incremental predictive value of high future oriented earnings disclosures for anticipating future earnings is given by the coefficient on $D^{*} X_{t 3}$. The coefficient on $D^{*} X_{t 3}$ is 0.27 with a p-value of 0.004 . This significantly positive coefficient indicates that high disclosure firms exhibit higher levels of share price anticipation of earnings three years ahead than low disclosure firms. Thus, the effect of future oriented earnings disclosures, on prices leading earnings, is in line with the previous research (i.e. Hussainey and Walker, 2009). The results suggest that future oriented earnings statements in corporate annual report narratives - as a measure of disclosure quality - contain value relevant information for the stock market participants. Table 3 also shows that the coefficient estimate on $D^{*} E P_{t-1}$ is negative and statistically significant at the 1 per cent level. This could be interpreted as demonstrating that, for high DQ firms, much of the positive effect of high EPS had already been priced in by the time of $R_{t}$.

\subsection{DISCLOSURE QUALITY AND STOCK RETURNS}

Table 4 shows that the average portfolio returns for firms without a DQ score are lower than the average portfolio returns for firms with a DQ score. Moreover, although not entirely monotonic, average portfolio returns decrease as the DQ score increases. This is consistent with the US and UK evidence (i.e. Gietzmann and 
Ireland, 2005; Francis and Nanda, 2008) that firms with good disclosure quality have lower cost of capital than firms with poor disclosure quality.

Table 4 further illustrates a monotonic increase in average firm size as the portfolios move from low to high DQ scores. The third column of table 4 illustrates that the natural logarithm of market equity increases from 5.16 for the low DQ portfolio to 7.64 for the high DQ portfolio. This result is in agreement with previous literature that suggests a positive relationship between a firm's size and its disclosure level (see, for example, Chavent et al., 2006).

Moreover, Table 4 demonstrates that portfolios with the highest DQ score have lower average book-to-market ratios than the average book-to-market ratio for zero or low DQ score firms. This is inconsistent with Hussainey and Walker (2009), who find that low book-to-market (growth) stocks disclose more information than high book-tomarket (value) stocks.

We then considered whether there is any evidence that markets systematically underor over-price DQ activity. We ran equation (6) on the zero DQ and the five DQ portfolios. The results are reported below in Table 5 .

We explain in section 4.2 that if abnormal returns $\left(\alpha_{i}\right)$ is less (more) than zero then the portfolio is overpriced (underpriced). Panels A and B of Table 5 reveal that the zero DQ portfolio is insignificantly overpriced having a negative and insignificant abnormal return (-0.88 and -1.12 respectively). Moreover, the remaining DQ portfolios are insignificantly under-priced having positive and insignificant abnormal 
returns, apart from the fourth DQ portfolio having negative though insignificant abnormal return. Overall, if taken at face value, the results suggest that DQ portfolios are correctly priced, with the abnormal returns insignificantly different from zero for all DQ portfolios. The results could be taken to imply that the UK stock market does understand firms with different levels of DQ intensity.

We now turn to the final question asked in this section - is the addition of a DQ 'factor' a useful addition to the Fama-French three factor model in explaining both the six DQ portfolios and the twenty industry returns in the UK.

Estimates of equation (6) on the six DQ portfolios suggest that adjustment of the Fama- French model to allow for DQ factor can generate significant improvements in the ability of the Fama-French model to explain portfolio returns. Table 5 provides the results from estimating the Fama-French model, and the modified factor model, for each of the six portfolios formed on the basis of DQ. Panel A of Table 5 provides evidence that the Fama- French model explains between $46.98 \%$ and $77.78 \%$ of the time-series variation in the returns on these portfolios. The explanatory power is lowest for portfolios comprising firms with low levels of DQ. The results in Panel B of Table 5 indicate that the modified factor model generally outperforms the FamaFrench model in explaining portfolio returns. Adjusted- $\mathrm{R}^{2}$ statistics increases for all portfolios, apart from portfolio 3 where the adjusted- $\mathrm{R}^{2}$ slightly declines from $56.13 \%$ to $64.71 \%$.

Moreover, the loadings on the DQ factor are positive (as expected), and significant for the zero and the two lowest DQ portfolios, while negative (as expected), and 
significant for portfolio 4. We interpreted the results for the zero and the two lowest DQ portfolios as well as portfolio 4 by suggesting that the DQ factor cancels out DQrelated information embedded in the other three factors. Comparison between Panels A and B of Table 5 shows that adding the DQ factor generally decreases the significance of the loading on the market factor, SMB and HML.

However, loadings on the DQ factor are insignificant for portfolios 3 and 5. The market factor dominates other risk factors in explaining the excess returns for portfolio 3; while the market factor, together with HML are the only significant risk factors for the highest DQ portfolio (portfolio 5). This suggests that the DQ factor could not explain the excess returns of these two portfolios, and that HML probably captures all the information related to disclosure quality in the highest DQ portfolio.

Kan and Zhang (1999) argue that testing the individual significance of the loadings on different risk factors says little, if anything, about the usefulness of a risk factor. Therefore, they suggest testing whether the loadings of the portfolios, with respect to a particular factor, are jointly significantly different from zero in the time-series regression. This will indicate whether the risk factor is useful in pricing portfolios, or if it is only a proxy, or useless factor.

The SUR model with identical regressors is quite common in asset pricing tests (Greene, 2003). In addition to applying the equation by equation ordinary least square estimates to produce $t$-statistics for each coefficient in every regression, we use the SUR to produce the F-statistics for the joint significance of each set of six coefficient estimates from the six regressions estimated as a SUR model. 
Therefore, we address Kan and Zhang's (1999) concerns and follow Petkova (2006) in reporting the $F$-statistics, and their corresponding $p$-values, from a seemingly unrelated regressions (SUR) model for the joint significance of the loadings.

The $F$-statistics values, from the SUR, in both Panels A and B of Table 5 suggest that the DQ factor is a useful factor in explaining stock returns $(\mathrm{F}=64.37$, $\mathrm{p}$-value $<0.01)$. Moreover, the joint significance of the remaining risk factors decreases with the inclusion of the DQ factor in the model. The results are consistent with the correlations reported in Table 1 which show quite complex interactions between the DQ factor and the remaining three factors.

For robustness, we addressed Lo and Mackinlay's (1990) concerns, we examined the comparative performance of the Fama-French model and the modified factor models in explaining the returns of industry portfolios. The results for the industry portfolios are given in Table 6 (Panels A and B). We ran equation (7) without a DQ factor to examine the usefulness of the possible risk factors in the Fama-French model before the introduction of DQ factor. We reported the results of the Fama-French model in Panel A. Then, we re-ran equation (7) with the full set of factors and reported the results in Panel B.

Panel A, Table 6 shows that the $p$-values from $F$-test for the joint significance of the loadings are less than 5\%. This result is consistent with Michou et al's (2007) findings that SMB, HML and excess market returns are useful factors in explaining the timeseries variation of industry returns in the UK. 
Panel B, Table 6 confirms the usefulness of the previous three factors with p-values less than $5 \%$. Moreover, the $F$-stats from SUR show the DQ factor is a useful risk factor with a $p$-value of $4 \%$. Moreover, it shows that the significance of the market factor and HML as measured by $F$-stats slightly declines when a DQ factor is added to the model. This last result suggested that the market factor and HML factor partially capture effects related to disclosure quality.

However, a comparison between Panel A and B of Table 6 illustrated that adjusted- $\mathrm{R}^{2}$ slightly declines for 12 out of 20 portfolios when a DQ factor is added to the FamaFrench model. This result could be due to the correlation between the DQ factor and Fama-French factors reported in Panel B of Table 1. Again, this would suggest that Fama-French factors contain some information about disclosure quality.

Overall, the empiricism reported upon in this, and the previous section, suggests that the UK stock market is not fooled by different levels of DQ in the sense that there is no systematic mis-pricing. Finally, a factor reflecting the return differences between high and low DQ score firms appears to be useful in explaining the time-series variation in industry portfolio returns.

\section{SUMMARY AND CONCLUSION}

This paper builds on prior research that investigates the importance of the disclosure quality for stock market participants. For the sake of completeness, we re-examined the value relevance of future oriented earnings statements in the annual report narratives for predicting future earnings. We then investigated the relation between disclosure quality and stock returns for a large sample of firms over the period July 
1997 to June 2004. Finally, we constructed a disclosure quality DQ factor and added it to Fama-French three-factor model in order to investigate the usefulness of such a factor in explaining the time-series variation of UK portfolio returns over and above the role of the original Fama-French factors.

Our results show that future oriented earnings statements in the annual report narratives increase the stock market's ability to anticipate future earnings change three years ahead. This is consistent with a recent study by Hussainey and Walker (2009). We also find that firms with poor disclosure quality, in general, have higher costs of capital than firms with good disclosure quality. This result is consistent with previous research, for example, Gietzmann and Ireland, 2005; Francis and Nanda, 2008, and theories that demonstrate a role for information risk (proxied here by disclosure quality) in asset pricing.

Finally, the time-series analysis suggest that allowing for a disclosure quality factor in constructing the asset pricing model can be important. The DQ factor is significant in pricing excess returns of UK portfolios, sorted on the basis of disclosure quality and industry. However, for the industry portfolios, the Fama-French model generally shows more explanatory power than the model with a DQ factor. This result can be explained by the fact that three factors in the Fama-French model (especially HML) partially capturing effects related to disclosure quality. 


\section{REFERENCES}

Barry, C.B., and S.J. Brown, (1985), "Differential information and security market equilibrium". The Journal of Financial and Quantitative Analysis, 20, 407-422.

Beattie, V., B. McInnes, and S. Fearnley, (2002), Through the Eyes of Management: A Study of Narrative Disclosures. Research Report, London: ICAEW.

Beretta, S. and Bozzolan, S. (2004), "A framework for the analysis of firm risk communication". The International Journal of Accounting, 39, 265- 288.

Beretta, S. and Bozzolan, S. (2008), "Quality versus quantity: the case of forwardlooking disclosure". Journal of Accounting, Auditing and Finance, 23 (3), 333-375.

Berk, J. B., (2000), "Sorting out Sorts", The Journal of Finance, 55, 407-427.

Botosan, C. A., (1997), "Disclosure level and the cost of equity capital". The Accounting Review, 72 (3), 323-349.

Bujaki, M., D. Zeghal, and R. Bozec, (1999), "The disclosure of future oriented information in annual reports of Canadian corporations". Working Paper: 44 (University of Ottawa, Canada).

Chavent, M., Y. Ding, L. Fu, H. Stolowy, and H. Wang, (2006), "Disclosure and determinants studies: an extension using the Divisive Clustering Method (DIV)". European Accounting Review, 15, 181-218

Clarkson, P. M., A. Dontoh, G. D. Richardson, and S. Sefcik, (1992), "The voluntary inclusion of earnings forecasts in IPO prospectuses". Contemporary Accounting Research, 8 (2), 601-626.

Clarkson, P., J. Guedes, and R. Thompson, (1996), "On the diversification, observability, and measurement of estimation risk". The Journal of Financial and Quantitative Analysis, 31, 69-84

Clarkson, P. M., J. L. Kao, and G. D. Richardson, (1994), "The voluntary inclusion of forecasts in the MD\&A section of annual reports". Contemporary Accounting Research, 11 (1-II), 423-450.

Clatworthy, M. and M. J. Jones, (2003), "Financial reporting of good news and bad news: evidence from accounting narratives". Accounting and Business Research, 33 (3), 171-185.

Core, J.E., W.R. Guay, and D. Verdi, (2008), "Is accruals quality a priced risk factor?". Journal of Accounting and Economics, 46, 2-22.

Coles, J.L., and U. Loewenstein, (1988), "Equilibrium pricing and portfolio composition in the presence of uncertain parameters". Journal of Financial Economics, 22, 279-303. 
Coles, J.L., U. Loewenstein, and J. Suay, (1995), "On equilibrium pricing under parameter uncertainty". The Journal of Financial and Quantitative Analysis, 30, 347364.

Collins, D.W., S.P. Kothari, J. Shanken, and R.G. Sloan, (1994), "Lack of timeliness and noise as explanations for the low contemporaneous return-earnings association". Journal of Accounting and Economics, 18(3), 289-324.

Diamond, D.W., and R.E. Verrecchia, (1991), "Disclosure, liquidity, and the cost of capital". The Journal of Finance, 46, 1325-1359.

Dimson, E., S. Nagel, and G. Quigley, (2003), "Capturing the value premium in the United Kingdom". Financial Analysts Journal, 59, 35-45.

Easley, D., and M. O'Hara, (2004), "Information and the cost of capital". Journal of Finance, 59, 1553-1584.

Espinosa, M.N., and M. Trombetta, (2007), "Disclosure interactions and the cost of equity capital: evidence from the Spanish continuous market". Journal of Business Finance \& Accounting, 34, 1371-1392.

Fama, E. F., (1991), "Efficient capital markets: II", The Journal of Finance, 46, 15751617.

Fama, E. F., and K. R. French, (1992), "The cross-section of expected stock returns". The Journal of Finance, 47, 427-465.

Fama, E. F., and K. R. French, (1993), "Common risk factors in the returns on stocks and bonds", Journal of Financial Economics, 33, 3-56.

Fama, E. F., and K. R. French, (1996), "Multifactor explanations of asset pricing anomalies", Journal of Finance, 51, 55-84.

Francis, J., R. LaFond, P. Olsson, and K. Schipper, (2005), "The market pricing of accruals quality". Journal of Accounting and Economics, 39, 295-327.

Francis, J. and D. Nanda, (2008), "Voluntary disclosure, earnings quality and cost of capital", Journal of Accounting Research, 46, 1, 53-99.

Gelb, D.S. and P. Zarowin, (2002), "Corporate disclosure policy and the informativeness of stock prices". Review of Accounting Studies, 7, 33-52.

Gibbons, M. R., S. Ross, and J. Shanken, (1989), "A test of the efficiency of a given portfolio", Econometrica (1986-1998) 57, 1121-1152.

Gietzmann, M. B., and J. Ireland, (2005), "Cost of capital, strategic disclosures and accounting choice". Journal of Business Finance and Accounting, 32, 599-634.

Greene, W. H., 2003, Econometric Analysis, Prentice Hall, New Jersey. 
Handa, P., and S.C. Linn, (1993), "Arbitrage pricing with estimation risk". The Journal of Financial and Quantitative Analysis, 28, 81-100.

Hanlon M., Myers, J., and Shevlin, T. (2007). 'Are dividends informative about future earnings?' Working paper, University of Michigan.

Healy, P.M. and G. Palepu, (2001), "Information asymmetry, corporate disclosure and capital markets: a review of the empirical disclosure literature". Journal of Accounting and Economics, 31 (1-3): 405-440.

Hopkins, P., (1996), "The effect of financial statement classification of hybrid financial instruments on financial analysts' stock price judgements". Journal of Accounting Research, 34 (Supplement), 33-50.

Hussainey, K. (2004), A Study of the Ability of (Partially) Automated Disclosure Scores to Explain the Information Content of Annual Report Narratives for Future Earnings, $\mathrm{PhD}$ thesis, Manchester University, Manchester.

Hussainey, K., T. Schleicher, and M. Walker, (2003), "Undertaking large-scale disclosure studies when AIMR-FAF ratings are not available: the case of prices leading earnings". Accounting and Business Research, 33(4), 275-294.

Hussainey, K. and M. Walker, (2009), "The effects of voluntary disclosure policy and dividend propensity on prices leading earnings". Accounting and Business Research, 39 (1), 37-55.

Kang, H.G., (2004), "Disclosure-risk premium: asset pricing under asymmetric information, manipulation and ambiguity". [Internet document] (October 28, 2004), Available from SSRN: http://ssrn.com/abstract=612922.

Kan, R., and C. Zhang, (1999), "Two-pass tests of asset pricing models with useless factors", Journal of Finance, 54, 203-235.

King, R. (1996), "Reputation formation for reliable reporting: an experiment investigation". The Accounting Review, 71 (3), 375-396.

Leuz, C., and R. Verrecchia, (2005), "Firms' capital allocation choices, information quality, and the cost of capital". Working Paper (University of Pennsylvania, Pennsylvania, USA).

Lev, B. (1989), "On the usefulness of earnings: lessons and directions from two decades of empirical research", Journal of Accounting Research, Vol. 27 Supplement, 153-192.

Lo, A. W., and A. C. MacKinlay, (1990), "Data-snooping biases in tests of financial asset pricing models", The Review of Financial Studies, 3, 431-467.

Lundholm, R.J. and Myers, L.A. (2002). "Bringing the future forward: the effect of disclosure on the returns-earnings relation". Journal of Accounting Research, 40(3), 809-39. 
Michou, M., S. Mouselli, and A.W. Stark, (2007), "Estimating the Fama and French factors in the UK- an empirical review", Manchester Business School Working Paper. (University of Manchester, Manchester, England).

Newey, W.K., and K.D. West, (1987), "A simple, positive semi-definite, heteroskedasticity and autocorrelation consistent covariance matrix", Econometrica 55, 703-708.

O'Hara, M., (2003), "Presidential address: liquidity and price discovery". Journal of Finance, 58, 1335-1354.

Orpurt, S and Zang, Y. (2009). "Do direct cash flow disclosures help predict future operating cash flows and earnings? ". The Accounting Review, 84 (3), 893-935

Oswald, D. R. and Zarowin, P. (2007). "Capitalization of R\&D and the informativeness of stock prices". European Accounting Review, 16(4), 703-726.

Petersen, M.A. (2008). "Estimating standard errors in finance panel data sets: comparing approaches ". Review of Financial Studies, Forthcoming.

Petkova, R., (2006). "Do the Fama-French factors proxy for innovations in predictive variables? ", The Journal of Finance, 61, 581-612.

Schleicher, T. (1996). Corporate Financial Disclosure and Share Price Anticipation of Earnings. MPhil Dissertation, Manchester University, Manchester, UK.

Schleicher, T., K. Hussainey, and M. Walker, (2007), "Loss firms' annual report narratives and share price anticipation of earnings". The British Accounting Review, 39(2), 153-171.

Warfield, T. D. and Wild, J. J. (1992). 'Accounting recognition and the relevance of earnings as an explanatory variable for returns'. The Accounting Review, 67 (4), 82142. 


\section{TABLES}

Table 1 Summary Statistics For, and Correlations Between, the Risk Factors

\begin{tabular}{|c|c|c|c|c|}
\hline \multicolumn{5}{|c|}{ Panel A - Summary Statistics for Monthly Returns } \\
\hline & $R_{m}-R_{f}$ & $S M B$ & $H M L$ & $D Q$ \\
\hline Mean & -0.00055 & 0.00283 & 0.007148 & 0.00068 \\
\hline Median & 0.002136 & 0.006029 & 0.004805 & 0.0019 \\
\hline Std. Dev. & 0.045341 & 0.039416 & 0.037698 & 0.038861 \\
\hline \multicolumn{5}{|c|}{ Panel B - Correlations } \\
\hline & $R_{m}-R_{f}$ & $S M B$ & $H M L$ & $D Q$ \\
\hline$R_{m}-R_{f}$ & 1 & -0.11 & $-0.25 * *$ & 0.13 \\
\hline$S M B$ & & 1 & $-0.29 * * *$ & $0.41 * * *$ \\
\hline$H M L$ & & & 1 & $-0.57 * * *$ \\
\hline$D Q$ & & & & 1 \\
\hline
\end{tabular}

Note:

$R_{M t}$ is the return on the market for month $\mathrm{t} ; R_{f t}$ is the risk-free return for month $\mathrm{t} ; S M B_{t}$ is the size factor return for month $\mathrm{t} ; H M L_{t}$ is the book-to-market factor for month $\mathrm{t} ; D Q_{t}$ is the return for month $\mathrm{t}$ for the $\mathrm{DQ}$ factor. The significance levels (two-tail test) are: $*=10 \%, * *=5 \%, * * *=$ $1 \%$. 
Table 2 Industry Portfolios' Descriptive Statistics for the Period 1997(7)-2004(6)

\begin{tabular}{|c|c|c|c|c|}
\hline Industry & $\begin{array}{c}\text { Average } \\
\text { Value- } \\
\text { Weighted } \\
\text { Monthly } \\
\text { Returns \% }\end{array}$ & $\begin{array}{c}\text { Ave. } \\
\text { No. of } \\
\text { Stocks }\end{array}$ & $\begin{array}{c}\text { Average } \\
M V\end{array}$ & $\begin{array}{c}\text { Average } \\
B M\end{array}$ \\
\hline 1.Oil and Gas & 0.81 & 29 & 730.07 & 0.78 \\
\hline 2.Chemicals & 0.50 & 24 & 577.37 & 0.68 \\
\hline 3.Basic Resources & 1.25 & 30 & 1048.78 & 1.06 \\
\hline 4.Construction and Materials & 0.87 & 61 & 335.19 & 0.89 \\
\hline 5.Aerospace and Defence & 1.40 & 12 & 904.83 & 0.32 \\
\hline 6.General Industrials & 1.50 & 12 & 103.04 & 0.84 \\
\hline 7.Electronic and Electrical Equipment & 0.75 & 48 & 204.48 & 0.63 \\
\hline 8.Industrial Engineering & 0.28 & 75 & 165.70 & 0.84 \\
\hline 9.Industrial Transportation & 0.60 & 32 & 477.99 & 0.73 \\
\hline 10.Support Services & 0.29 & 129 & 201.30 & 0.49 \\
\hline 11.Automobiles and Parts & 0.81 & 24 & 298.02 & 1.03 \\
\hline 12.Food and Beverages & 0.76 & 48 & 885.61 & 0.96 \\
\hline 13.Personal and Household Goods & 1.46 & 105 & 167.26 & 1.10 \\
\hline 14.Healthcare & 0.25 & 66 & 1417.23 & 0.42 \\
\hline 15.Food and Drug Retailers & 0.78 & 36 & 1525.67 & 0.67 \\
\hline 16.General Retailers & 0.82 & 62 & 596.47 & 0.65 \\
\hline 17.Media & 0.29 & 66 & 368.46 & 0.47 \\
\hline 18.Travel and Leisure & 0.49 & 98 & 331.13 & 0.77 \\
\hline 19.Technology & 0.02 & 125 & 249.01 & 0.44 \\
\hline 20.Utilities & 0.65 & 33 & 4595.22 & 0.67 \\
\hline
\end{tabular}

Note:

In June each year from July 1997 to June 2004, stocks are sorted into 20 value-weighted portfolios using LSPD G17 codes and FTSE Industrial Classification Benchmark (ICB) ${ }^{4}$. Firm size is measured as the number of shares outstanding multiplied by the stock price at the end of June. BM is measured equity capital and reserves minus total intangibles at the end of December of previous year.

\footnotetext{
${ }^{4}$ Utilities include Telecommunication, Electricity, Gas, Water and other companies
} 
Table 3 The Value Relevance of Disclosure Quality

\begin{tabular}{|l|c|}
\hline \multicolumn{1}{|c|}{ Independent variable } & Coefficient estimate \\
\hline Intercept & -0.02 \\
& $(0.376)$ \\
\hline$X_{t}$ & $1.53^{* * *}$ \\
\hline$X_{t 3}$ & $(0.001)$ \\
\hline$R_{t 3}$ & $0.48^{* * *}$ \\
& $(0.001)$ \\
\hline$A G_{t}$ & -0.05 \\
& $(0.001)$ \\
\hline$E P_{t-1}$ & $0.09^{* * *}$ \\
\hline$D$ & $(0.001)$ \\
\hline$D^{*} X_{t}$ & $1.09^{* * *}$ \\
& $(0.001)$ \\
\hline$D^{*} X_{t 3}$ & 0.01 \\
& $(0.604)$ \\
\hline$D^{*} R_{t 3}$ & 0.14 \\
& $(0.305)$ \\
\hline$D^{*} A G_{t}$ & $0.27 * * *$ \\
& $(0.004)$ \\
\hline$D^{*} E P_{t-1}$ & 0.02 \\
& $(0.126)$ \\
\hline $\mathrm{R}^{2}$ & 0.01 \\
& $(0.615)$ \\
\hline & $-0.36^{* * *}$ \\
& $(0.001)$ \\
\hline & 3528 \\
\hline & 0.134 \\
\hline
\end{tabular}

Note:

Stock returns, $R_{t}$, is calculated as buy-and-hold returns from eight months before the financial year-end to four months after the financial year-end. $R_{t 3}$ is the aggregated three years future period returns. The earnings variable, $X_{t}$, is defined as earnings change per share deflated by the share price four months after the end of the financial year $t-1 . X_{t 3}$ is the aggregated three years future earnings change Earnings measure is the Worldscope item 01250 which is operating income before all exceptional items. $A G_{t}$ is the growth rate of total book value of assets for period $t$ (Datastream item 392). $E P_{t-1}$ is defined as period $t-1$ 's earnings over price four months after the financial year-end of period $t-1$. Firms with a disclosure score in the top (bottom) $50 \%$ of the distribution of disclosure scores are defined as high (low) disclosure firms. The dummy variable, $D$, is set equal to 1 (0) for high (low) disclosure firms. The significance levels (two-tail test) are: $*=10 \%, * *=5 \%, * * *=1 \%$. 
Table 4 Mean Values for Non-DQ and DQ portfolios

\begin{tabular}{|c|c|c|c|c|}
\hline Portfolio & $\begin{array}{c}\text { Monthly } \\
\text { Return (\%) }\end{array}$ & $\ln (\mathbf{M E )}$ & BM & DQ \\
\hline 0 & -1.06 & 5.54 & 0.77 & 0 \\
\hline Low & 0.99 & 5.16 & 0.77 & 1.16 \\
\hline 2 & 0.69 & 5.78 & 0.81 & 2.57 \\
\hline 3 & 0.60 & 6.09 & 0.74 & 4.07 \\
\hline 4 & 0.13 & 6.69 & 0.74 & 5.85 \\
\hline High & 0.41 & 7.64 & 0.74 & 10.51 \\
\hline
\end{tabular}

Note: Monthly returns are value-weighted returns. BM is the ratio of book equity to market equity. ME is the market equity. DQ is the disclosure quality score. All ratios are computed at the end of June of year t. Portfolios are formed annually based on DQ. Portfolio 0 comprises all firms with zero DQ for year t. Portfolio low comprises the lowest quintile of firms sorted on the basis of DQ while portfolio High comprises the highest quintile of firms based on DQ. 
Table 5 Regressions of Excess Returns For Six DQ Portfolios on the Market Factor, SMB and HML (Panel A) and the Market factor, SMB, HML, and DQF (Panel B)

\begin{tabular}{|c|c|c|c|c|c|c|c|c|c|c|c|}
\hline & $\alpha$ & $\beta_{M}$ & $\beta_{\mathrm{HML}}$ & $\beta_{\mathrm{SMB}}$ & $\beta_{\mathrm{DQ}}$ & $\mathrm{t}(\alpha)$ & $\mathrm{t}\left(\beta_{\mathrm{M}}\right)$ & $\mathrm{t}\left(\beta_{\mathrm{HML}}\right)$ & $\mathrm{t}\left(\beta_{\mathrm{SMB}}\right)$ & $\mathrm{t}\left(\beta_{\mathrm{DQ}}\right)$ & Adj-R ${ }^{2}$ \\
\hline \multicolumn{12}{|c|}{ Panel A: $\mathrm{R}_{\mathrm{p}}-\mathrm{R}_{\mathrm{f}}=\alpha+\beta_{\mathrm{M}}\left(\mathrm{R}_{\mathrm{M}}-\mathrm{R}_{\mathrm{f}}\right)+\beta_{\mathrm{HML}} \mathrm{HML}+\beta_{\mathrm{SMB}} \mathrm{SMB}+\varepsilon$} \\
\hline $\mathrm{DQ}=0$ & -0.88 & 1.1206 & -0.8355 & 0.2362 & & -1.22 & 5.94 & -3.65 & 1.30 & & 52.05 \\
\hline Low & 0.80 & 0.8858 & -0.4011 & 0.4016 & & 1.35 & 6.03 & -2.35 & 2.32 & & 46.98 \\
\hline 2 & 0.51 & 1.0210 & -0.3786 & 0.3311 & & 1.49 & 9.11 & -2.87 & 2.40 & & 62.52 \\
\hline 3 & 0.08 & 0.9374 & 0.1357 & 0.1975 & & 0.29 & 9.63 & 1.07 & 1.76 & & 65.13 \\
\hline 4 & -0.35 & 1.0841 & 0.1337 & 0.1360 & & -0.76 & 13.33 & 1.05 & 1.41 & & 61.79 \\
\hline High & 0.20 & 0.7772 & -0.1760 & -0.1217 & & 1.07 & 14.24 & -2.74 & -1.90 & & 77.78 \\
\hline $\mathbf{F}$ & 1.05 & $>100$ & 8.47 & 3.97 & & & & & & & \\
\hline P-value & 0.40 & $<0.01$ & $<0.01$ & $<0.01$ & & & & & & & \\
\hline \multicolumn{12}{|c|}{ Panel B: $R_{p}-R_{f}=\alpha+\beta_{M}\left(R_{M}-R_{f}\right)+\beta_{H M L} H M L+\beta_{S M B} S M B+\beta_{D Q} D Q+\varepsilon$} \\
\hline $\mathrm{DQ}=0$ & -1.12 & 1.0954 & -0.4908 & 0.0456 & 0.6928 & -1.55 & 5.93 & -2.38 & 0.21 & 2.99 & 56.92 \\
\hline Low & 0.61 & 0.8652 & -0.1204 & 0.2464 & 0.5640 & 1.11 & 6.30 & -0.87 & 1.45 & 2.65 & 52.54 \\
\hline 2 & 0.27 & 0.9958 & -0.0356 & 0.1414 & 0.6893 & 0.88 & 10.40 & -0.22 & 1.15 & 3.78 & 72.37 \\
\hline 3 & 0.09 & 0.9382 & 0.1251 & 0.2033 & -0.0212 & 0.31 & 9.55 & 0.90 & 1.60 & -0.19 & 64.71 \\
\hline 4 & -0.24 & 1.0960 & -0.0289 & 0.2260 & -0.3268 & -0.50 & 12.80 & -0.17 & 2.20 & -2.59 & 64.14 \\
\hline High & 0.23 & 0.7805 & -0.2209 & -0.0969 & -0.0901 & 1.26 & 13.67 & -3.13 & -1.44 & -1.16 & 77.92 \\
\hline $\mathbf{F}$ & 0.88 & $>100$ & 3.1 & 2.21 & 64.37 & & & & & & \\
\hline P-value & 0.51 & $<0.01$ & $<0.01$ & 0.04 & $<0.01$ & & & & & & \\
\hline
\end{tabular}

Notes:

(i) Following Petkova (2006), Table 5 reports the loadings from individual time-series regressions for the six portfolios, the t-statistics for the significance of the alpha (intercept) and beta (slope) coefficients, and the adjusted- $\mathrm{R}^{2}$ from these regressions.

(ii) The corresponding t-statistics are also reported and they are corrected for heteroscedasticity and serial correlation, using the Newey-West (1987) estimator with five lags.

(iii) The intercepts are in percentages and the sample period is from July 1997 to June 2004.

(iv) The final two rows report F-test statistics for the joint significance of each set of six coefficient estimates from the six regressions estimated as a Seemingly Unrelated Regressions system. For the alpha (intercept) coefficients, the GRS F-test for the joint significance of the six intercepts is reported. For the beta (slope) coefficients, standard F-tests for the joint significance of each set of six coefficient estimates are reported. 
Table 6 Loadings from Time-Series Regressions on 20 Industry Portfolios Panel A: Loadings on the FF Factors from Time-Series Regressions

\begin{tabular}{|c|c|c|c|c|c|c|c|c|c|}
\hline Industry & $\alpha$ & $\mathrm{t}_{\alpha}$ & $\beta_{\mathrm{M}}$ & $\mathrm{t}_{\beta(\mathrm{M})}$ & $\beta_{\mathrm{SMB}}$ & $\mathrm{t}_{\beta(\mathrm{SMB})}$ & $\beta_{\mathrm{HML}}$ & $\mathrm{t}_{\beta(\mathrm{HML})}$ & Adj- $^{2}$ \\
\hline 1 & -0.07 & -0.07 & 0.79 & 3.04 & 0.52 & 2.21 & 0.50 & 1.63 & 16.12 \\
\hline 2 & -0.22 & -0.53 & 0.95 & 7.83 & 0.38 & 2.38 & 0.35 & 2.69 & 46.93 \\
\hline 3 & 0.40 & 0.55 & 1.43 & 7.38 & 0.30 & 1.69 & 0.61 & 2.58 & 49.04 \\
\hline 4 & -0.08 & -0.18 & 1.13 & 9.98 & 0.48 & 3.46 & 0.65 & 5.88 & 58.31 \\
\hline 5 & 0.59 & 0.89 & 1.39 & 10.11 & 0.09 & 0.38 & 0.64 & 3.17 & 46.37 \\
\hline 6 & 0.87 & 1.74 & 0.61 & 6.49 & 0.47 & 4.47 & 0.17 & 1.80 & 28.91 \\
\hline 7 & 0.02 & 0.02 & 1.88 & 6.62 & 1.33 & 4.27 & 0.07 & 0.28 & 54.45 \\
\hline 8 & -0.63 & -1.29 & 1.17 & 7.80 & 0.62 & 5.12 & 0.54 & 3.27 & 57.17 \\
\hline 9 & -0.10 & -0.25 & 1.03 & 7.47 & 0.38 & 3.33 & 0.34 & 2.13 & 58.67 \\
\hline 10 & -0.22 & -0.63 & 1.07 & 12.90 & 0.58 & 7.44 & 0.00 & -0.02 & 68.63 \\
\hline 11 & 0.18 & 0.28 & 1.21 & 8.18 & 0.33 & 1.68 & 0.26 & 1.40 & 37.01 \\
\hline 12 & 0.08 & 0.19 & 0.58 & 3.74 & -0.04 & -0.31 & 0.44 & 1.88 & 27.16 \\
\hline 13 & 0.79 & 1.31 & 0.85 & 4.47 & -0.05 & -0.18 & 0.45 & 2.11 & 28.17 \\
\hline 14 & -0.17 & -0.31 & 0.57 & 4.74 & -0.24 & -1.53 & 0.14 & 0.95 & 21.36 \\
\hline 15 & 0.08 & 0.17 & 0.57 & 5.00 & -0.05 & -0.39 & 0.46 & 2.36 & 30.27 \\
\hline 16 & 0.17 & 0.34 & 0.84 & 5.26 & 0.24 & 1.53 & 0.31 & 1.19 & 33.09 \\
\hline 17 & 0.12 & 0.17 & 1.26 & 9.91 & 0.59 & 3.54 & -0.48 & -2.00 & 53.51 \\
\hline 18 & -0.39 & -0.84 & 1.19 & 8.57 & 0.41 & 3.15 & 0.59 & 3.79 & 63.14 \\
\hline 19 & 0.12 & 0.10 & 1.98 & 8.17 & 1.17 & 4.90 & -1.02 & -2.73 & 61.23 \\
\hline 20 & 0.70 & 1.35 & 0.89 & 5.13 & -0.35 & -2.13 & -0.44 & -1.70 & 47.18 \\
\hline F & 0.51 & & 59.63 & & 6.37 & & 6.49 & & \\
\hline P-value & 0.95 & & $<0.01$ & & $<0.01$ & & $<0.01$ & & \\
\hline
\end{tabular}


Panel B: Loadings on the FF + DQF Factors from Time-Series Regressions

\begin{tabular}{|c|c|c|c|c|c|c|c|c|c|c|c|}
\hline Industry & $\alpha$ & $\mathrm{t}_{\alpha}$ & $\beta_{\mathrm{M}}$ & $\mathrm{t}_{\beta(\mathrm{M})}$ & $\beta_{\mathrm{SMB}}$ & $\mathrm{t}_{\beta(\mathrm{SMB})}$ & $\beta_{\mathrm{HML}}$ & $\mathrm{t}_{\beta(\mathrm{HML})}$ & $\mathrm{B}_{\mathrm{DQ}}$ & $\mathrm{t}_{\beta(\mathrm{DQ})}$ & $\mathrm{Adj}-\mathrm{R}^{2}$ \\
\hline 1 & -0.03 & -0.03 & 0.79 & 3.03 & 0.54 & 2.52 & 0.45 & 1.28 & -0.10 & -0.38 & 15.20 \\
\hline 2 & -0.08 & -0.22 & 0.97 & 7.76 & 0.48 & 2.76 & 0.16 & 1.12 & -0.38 & -2.12 & 50.16 \\
\hline 3 & 0.33 & 0.47 & 1.42 & 7.17 & 0.25 & 1.28 & 0.71 & 2.69 & 0.19 & 1.01 & 48.86 \\
\hline 4 & -0.07 & -0.15 & 1.13 & 9.70 & 0.49 & 3.15 & 0.63 & 5.63 & -0.04 & -0.28 & 57.81 \\
\hline 5 & 0.73 & 1.13 & 1.40 & 10.20 & 0.20 & 0.88 & 0.43 & 1.58 & -0.42 & -1.47 & 47.85 \\
\hline 6 & 0.85 & 1.75 & 0.61 & 6.42 & 0.46 & 3.69 & 0.20 & 1.66 & 0.05 & 0.29 & 28.11 \\
\hline 7 & 0.11 & 0.12 & 1.89 & 6.53 & 1.41 & 3.91 & -0.07 & -0.22 & -0.27 & -0.93 & 54.33 \\
\hline 8 & -0.50 & -1.03 & 1.18 & 7.86 & 0.72 & 6.25 & 0.35 & 2.11 & -0.38 & -2.40 & 59.64 \\
\hline 9 & -0.07 & -0.18 & 1.03 & 7.44 & 0.40 & 3.35 & 0.30 & 1.83 & -0.08 & -0.66 & 58.34 \\
\hline 10 & -0.16 & -0.42 & 1.08 & 12.40 & 0.63 & 7.90 & -0.09 & -0.76 & -0.18 & -1.39 & 69.07 \\
\hline 11 & 0.19 & 0.29 & 1.21 & 8.06 & 0.33 & 1.55 & 0.25 & 1.11 & -0.03 & -0.09 & 36.23 \\
\hline 12 & 0.21 & 0.48 & 0.60 & 3.76 & 0.06 & 0.49 & 0.25 & 1.15 & -0.37 & -3.16 & 31.15 \\
\hline 13 & 0.73 & 1.24 & 0.84 & 4.41 & -0.09 & -0.39 & 0.53 & 2.81 & 0.17 & 0.59 & 27.85 \\
\hline 14 & -0.10 & -0.19 & 0.58 & 4.66 & -0.19 & -1.17 & 0.05 & 0.38 & -0.18 & -0.95 & 21.28 \\
\hline 15 & 0.10 & 0.21 & 0.58 & 4.97 & -0.03 & -0.25 & 0.43 & 2.18 & -0.05 & -0.39 & 29.51 \\
\hline 16 & 0.14 & 0.29 & 0.84 & 5.16 & 0.22 & 1.30 & 0.35 & 1.34 & 0.08 & 0.41 & 32.40 \\
\hline 17 & 0.01 & 0.01 & 1.25 & 10.03 & 0.50 & 3.12 & -0.32 & -1.48 & 0.31 & 1.29 & 54.04 \\
\hline 18 & -0.34 & -0.72 & 1.20 & 8.54 & 0.45 & 3.43 & 0.51 & 3.40 & -0.16 & -1.24 & 63.25 \\
\hline 19 & 0.09 & 0.07 & 1.98 & 7.81 & 1.15 & 4.34 & -0.98 & -2.03 & 0.09 & 0.25 & 60.78 \\
\hline 20 & 0.57 & 1.11 & 0.87 & 5.12 & -0.45 & -2.84 & -0.26 & -1.07 & 0.38 & 2.34 & 49.30 \\
\hline F & 0.48 & & 58.80 & & 6.78 & & 4.98 & & 1.63 & & \\
\hline P-value & 0.97 & & $<0.01$ & & $<0.01$ & & $<0.01$ & & 0.04 & & \\
\hline
\end{tabular}

Notes:

(i) Following Petkova (2006), Table 5 reports the loadings from individual time-series regressions for the 20 industry portfolios, the t-statistics for the significance of the alpha (intercept) and beta (slope) coefficients, and the adjusted- $\mathrm{R}^{2}$ from these regressions.

(ii) The corresponding t-statistics are also reported and they are corrected for heteroscedasticity and serial correlation, using the Newey-West (1987) estimator with five lags.

(iii) The sample period is from July 1997 to June 2004.

(iv) The final two rows report F-test statistics for the joint significance of each set of 20 coefficient estimates from the 20 regressions estimated as a Seemingly Unrelated Regressions system. For the alpha (intercept) coefficients, the GRS F-test for the joint significance of the 20 intercepts is reported. For the beta (slope) coefficients, standard F-tests for the joint significance of each set of 20 coefficient estimates are reported.

(v) The intercepts are in percentages. 